\title{
STIMULATION OF LATEX PRODUCTION IN SERINGUEIRA (HEVEA BRASILIENSIS L.) WITH ETRHEL DOSES ${ }^{1}$
}

\author{
Alessandro Teles da $\mathrm{Cruz}^{2 *}$, Joseanny Cardoso da Silva Pereira ${ }^{3}$ and Sara Raquel Mendonça ${ }^{2}$
}

\footnotetext{
${ }^{1}$ Received on 23.01.2017 accepted for publication on 04.10.2017.

${ }^{2}$ Faculdade Evangélica de Goianésia, Graduado em Agronomia, Goianésia, Goiás- Brasil. E-mail: <alessanteles@hotmail.com> and $<$ saramendonca31@hotmail.com>.

${ }^{3}$ Faculdade Evangélica de Goianésia, Doutora em Agronomia, Goianésia, Goiás - Brasil. E-mail: <josycard@yahoo.com.br>. *Corresponding author.
}

\begin{abstract}
The use of the Ethrel ${ }^{\circledR}$ stimulant on rubber cultivation has become essential to ensure greater rubber production. When applied on the cut of the tree, this stimulant releases the ethylene gas that causes an increase of the exudation period of the latex flow. Dilutions and applications should be performed correctly so that they do not cause tapping panel dryness, which would leave the plant unproductive for a long time. Thus, the objective of this study was to evaluate the effects of increasing doses of ethrel on tapping panel dryness and rubber production of rubber tree clones. Three experiments were conducted using a randomized block design with four treatments (ethrel doses) and three replicates. The clones used were RRIM600, PR255 and PB217 submitted to doses of the stimulant Ethrel 0\%, 2.5\%, 3.3\% and 5\% with an interval of application of 30 days. The $\mathrm{d} / 7$ bleeding system was used. The productive performance was evaluated monthly and the total of plants with tapping panel dryness at the end of the work. All clones presented a linear positive response to increasing doses. The dose of ethrel $5 \%$ favors higher rubber yields in the three evaluated clones, but is associated with high percentage of drying. Thus, it was concluded that the production of rubber is affected positively with the increase of ethrel doses, but this increase causes a higher incidence of panel drying. Thus, it is recommended to use the ethrel $2.5 \%$ dose so the production is guaranteed without causing the tapping panel dryness.
\end{abstract}

Keywords: Hevea brasiliensis; Natural rubber; Tapping panel dryness.

\section{ESTIMULAÇÃO DA PRODUÇÃO DE LÁTEX EM SERINGUEIRA (Hevea brasiliensis L.) COM DOSES DE ETHREL}

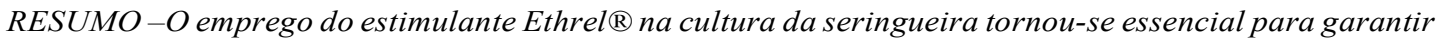
maiores produções de borracha. Ao ser aplicado no local do corte da árvore, esse estimulante libera o gás etileno que provoca o aumento do período de exsudação do fluxo do látex. As diluições e aplicações devem ser realizadas de forma correta para que não provoquem secamento nos painéis, o que deixaria a planta improdutiva por longo tempo. Dessa forma, objetivou-se avaliar os efeitos de doses crescentes de ethrel no secamento de painel e na produção de borracha de clones de seringueira. Conduziu-se três experimentos utilizando-se o delineamento em blocos casualizados com quatro tratamentos (doses de ethrel) e três repetições. Os clones utilizados foram RRIM600, PR255 e PB217 submetidos às doses do estimulante Ethrel 0\%, 2,5\%, 3,3\% e 5\% com intervalo de aplicação de 30 dias. Utilizou-se o sistema de sangria d/7. Foram avaliados o desempenho produtivo mensalmente e o total de plantas com secamento de painel ao término do trabalho. Todos os clones apresentaram resposta linear positiva ao aumento das doses. A dose de ethrel $5 \%$ favorece maiores produções de borracha nos três clones avaliados, mas está associada à alta porcentagem de secamento. Dessa forma, concluiu-se que a produção de borrracha de seringueira é afetada positivamente com o aumento das doses de ethrel, mas esse aumento provoca maior incidência de secamento de painel. Assim, recomenda-se a utilizaçãoda dose de ethrel 2,5\% pela garantia da produção sem provocar o secamento do painel de sangria.

Palavras-Chave: Hevea brasiliensis L.; Borracha natural; Secamento de painel. 


\section{INTRODUCTION}

The rubber tree is the popular name given to the plant of the genus Hevea, belonging to the family Euphorbiaceae, native to the Amazon region (Souza and Lorenzi, 2012). Among the eleven species of this genus, the Hevea brasilienses species is the most important and productive, standing out to produce latex of better quality (Gasparoto and Pereira, 1997). In order to enhance the production of latex, the use of stimulants in rubber trees was introduced in the 1980s. A number of substances were used, and ethrel (2-chloroethylphosphanic acid-Ethefon) was the most efficient (Gonçalves et al., 2000; Shi et al., 2016).

The ethrel when applied at the cutting site of the tree, releases the ethylene gas that causes an increase of the latex exudation period, because it induces a delay of the obstruction of the laticiferous vessels (Rojas et al., 2017). In addition, ethylene acts by increasing the sucrose hydrolysis, which results in the release of glucose and improves the supply of the carbon source to the biosynthesis of the rubber, increasing the period of exudation (Tupy and Primot, 1982). Thus, due to the increase in exudation time, higher rubber yields can be obtained (Gonçalves et al., 2000). Moreover, its use provides desirable latex characteristics, such as elasticity, flexibility and impermeability (Borracha Natural Brasileira, 2011).

As ethrel adoption provided greater release of latex, bleeding frequency decreased (Pereira et al., 2001), which resulted in a decrease in labor costs, considered the most expensive operation in commercial plantations (Rojas et al., 2017). Thus, the use of the ethrel stimulant in the rubber cultivation has become essential to ensure greater rubber yields.

Dilution and application of the stimulator product should be done correctly. The ethrel patent company recommends the application of a $3.3 \%$ dose (Ethrel $\mathrm{PA} \AA, 2005)$, while Moraes and Moraes (2001) recommend a dose of $2.5 \%$. Excessive doses of ethrel may cause tapping panel dryness, resulting in unproductivity of the plant (Benesi and Oliveira, 2000). In addition, the productive response of the clones and susceptibility to tapping panel dryness varies among the clones.

The tapping panel dryness is a physiological disturbance that occurs in the bleeding phase causing the impedance of the latex flow inside the stem bark, resulting in a total or partial reduction of the production
(Silva, 2008), which leads to drastic losses (10-40\%) annually in rubber production (Venkatachalam et al., 2007; Gébelin et al., 2013). This syndrome is associated with nutrient depletion and reduction of levels of proteins, nucleic acids, thiols and ascorbic acid, substances present in the elaborated sap of the rubber tree and that can be released with greater intensity with the increase of ethrel doses. In addition, the susceptibility of the disease probably depends on the clone (Gébelin et al., 2013). Thus, the objective was to evaluate the effects of increasing doses of Ethrel ${ }^{\circledR}$ on tapping panel dryness and rubber production of rubber tree clones.

\section{MATERIALAND METHODS}

The experiment was carried out at "Fazenda Água Doce" located in the city of Vila Propício, state of Goiás, with altitude of $690 \mathrm{~m}$, latitude of $15^{\circ} 13^{\prime} 20.9^{\prime \prime S}$ and longitude of $48^{\circ} 50^{\prime} 57.6^{\prime \prime} \mathrm{W}$, at region of the São Paulo Valley from October 2015 to July 2016 . The soil is classified as Red Latosol. The mean temperature was $23.9^{\circ} \mathrm{C}$ with a variation of $2.9^{\circ} \mathrm{C}$ during the year (ClimateData.org, 2016) and a mean monthly precipitation of $102 \mathrm{~mm}$ (Figure 1).

Three experiments were carried out using the experimental design in randomized blocks. Each experiment consisted of one clone (RRIM 600, PR 255 and PB 217) submitted to three doses of Ethrel PA ${ }^{\circledR}$ stimulant $(0 \%, 2.5 \%, 3.3 \%$ and $5.0 \%)$ with four replicates and three plants per replicate, totalizing twelve plants per treatment evaluated for 10 months. The above clones were chosen for their uniformity, high productivity, desirable peel thickness, annual leaf senescence and tolerance to pests and diseases (Corredato et al., 2014).

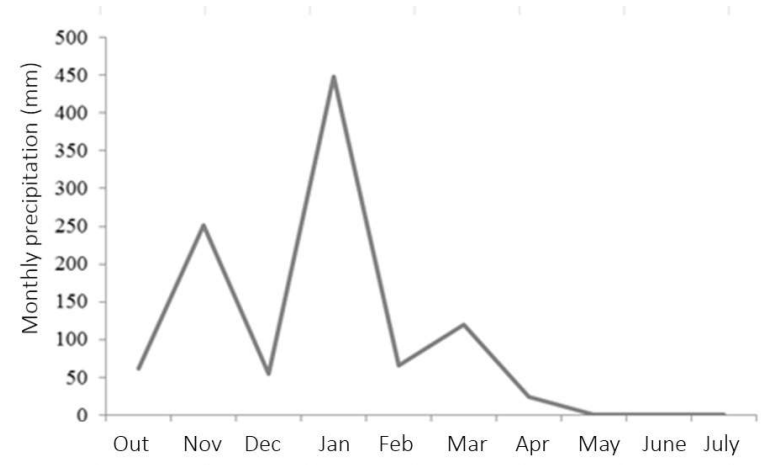

Figure 1 - Rainfall data.

Figura 1-Dados pluviométricos.

Revista Árvore. 2017;41(5):e410511 
The experiment was installed in a rubber tree with five years of production organized in spacings of 8.0 $\mathrm{m}$ between rows and $2.5 \mathrm{~m}$ between plants, with each plant having a breast height (também não sei dizer se isso é tecninco) of approximately $58 \mathrm{~cm}$. The 20 plants at the beginning of the lines were disregarded due to the greater presence of light, wind and temperature, factors that can interfere directly in the results.

In order to carry out the marking of the panel, the specific place where the bleeds were performed, the plant stems were measured with a $1.5 \mathrm{~m}$ tape measure and divided in half vertically, in order to obtain two equal parts. Afterwards, a flag was used, which was fixed to a thin strip, with a height of $1.3 \mathrm{~m}$ from the ground and a slope of $37^{\circ}$ to mark the panel (Benesi and Oliveira, 2000).

The panels were opened with the use of a "jebong" knife and then the assembly of the equipment: support spout, spring and mug with a capacity of three liters of latex. The bleeding system performed was $d / 7$, repeating the bleeding every seven days in the same plant at eight hours and thirty minutes. A pachymeter was used to measure the bleeding depth, being ideal 1.5 to $2.0 \mathrm{~mm}$ of bark before reaching the vascular exchange.

For the use of Ethrel P.A ${ }^{\circledR}$, a doser with a capacity of $40 \mathrm{ml}$ was used to obtain the desired doses for each treatment. The application was done with brush $3 / 4$ equivalent to $1 \mathrm{ml}$ of syrup per plant with a 30 day interval.

The productive data were collected monthly. The rubber was weighed with the aid of a $5 \mathrm{~kg}$ capacity scale and naturally coagulated. The evaluation of the percentage of plants that presented tapping panel dryness was performed at the end of the work.

Data were submitted to regression analysis and model adjustments were performed based on their significance and the coefficient of determination (R2). The software Assistat 7.7 was used.

\section{RESULTS}

After regression analysis, the model was linearly adjusted to the data obtained with significant $\mathrm{R} 2$ values at $5 \%$ probability for the three clones evaluated, indicating that the equations were adequate to describe the effect of the doses on the production of the clones. It was observed that the rubber production of the clones changed positively with increasing dose applied in the panel dryness.

The ethrel dose coefficient in clone PR 255 (Figure 2) shows that at each $1 \%$ increase in applied dose, rubber yield increased by $1.21 \mathrm{~kg}$. The $\mathrm{R}^{2}$ of 0.86 indicates that the linear model fits well with the means of rubber production obtained as a function of ethrel doses. The ethrel $5 \%$ dose provided in this clone the increase of $11.51 \mathrm{~kg}$ of rubber per plant, a $50 \%$ increase in yield of the control.

In the RRIM 600 clone, the increase in rubber production (Figure 2) was identical to that of clone PR 255, that is, at each 1\% increase in applied dose, the increase in rubber production of the plant was $1.21 \mathrm{~kg}$. The R2 of the equation for this clone was also high (0.92). Coefficient a' is lower for this clone, which indicates that rubber yields were lower in comparison to clone PR 255. The maximum dose of ethrel (5\%) provided rubber yield of $10.9 \mathrm{~kg}$ per plant.

Despite the increase in productivity with the increase of ethrel doses, it was observed that the higher doses resulted in a greater number of plants with panel dryness (Table 1). The PR 255 clone presented better response to stimulation and lower panel dryness index. The RRIM 600 clone also obtained good productivity, but with a higher percentage of plants with drying. The clone PB 217 expressed lower productive performance and high panel drying index.

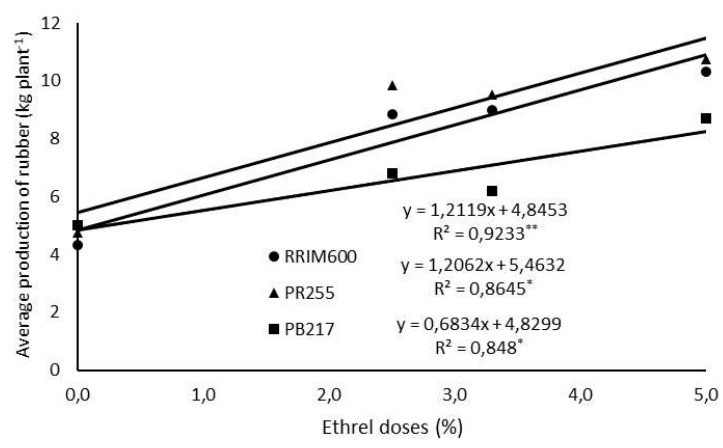

Figure 2 - Average production of rubber $\left(\mathrm{kg} \mathrm{plant}^{-1}\right)$ of clones RRIM600, PR 255 e PB 217 under ethrel stimulant doses in the fifth year of production.

Figura 2-Média de produção de borracha (kg planta-1) dos clones RRIM600, PR 255 e PB 217 sob doses do estimulante ethrel no quinto ano de produção. 
Table 1 - Tapping panel dryness in three rubber tree clones submitted to ethrel doses.

Tabela 1 - Secamento de painel em três clones de seringueira (Hevea brasiliensis L.) submetidos a doses de ethrel.

\begin{tabular}{|c|c|c|c|}
\hline \multirow{2}{*}{$\begin{array}{l}\text { Doses } \\
\text { PR } 255\end{array}$} & \multicolumn{3}{|c|}{ Tapping panel dryness(\%) } \\
\hline & $\begin{array}{c}\text { RRIM } \\
600 \text { clone }\end{array}$ & $\begin{array}{c}\text { PB } 217 \\
\text { clone }\end{array}$ & $\begin{array}{l}(\%) \\
\text { clone }\end{array}$ \\
\hline 0 & 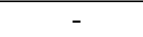 & 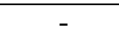 & - \\
\hline 2,5 & - & - & - \\
\hline 3,3 & - & 22,2 & 22,2 \\
\hline 5,0 & 11,1 & 22,2 & 33,3 \\
\hline
\end{tabular}

The lowest coefficient b', for ethrel doses, was found in clone PB 217 . With a $1 \%$ increase in applied ethrel dose, the increase in rubber production was only $0.68 \mathrm{~kg}$ (Figure 2). The 5\% dose provided rubber yield per plant of $8.3 \mathrm{~kg}$.

\section{DISCUSSION}

The productive increase resulting from the dose of $5 \%$, when compared to the dose of $3.3 \%$, was $13 \%$ in the RRIM 600 clone, $12 \%$ in the PR 255 clone and in the PB 217 clone was $28 \%$. Pereira et al. (2001) verified a productive increase of only $1 \%$ of the dose of $3.3 \%$ to that of $5 \%$. Thus, they recommended a dose of $3.3 \%$. In this work, the larger productive increments could compensate the application of larger doses. However, as the percentage of plants that showed drying was very high $(22 \%)$ (Table 1$)$, the use of this dose is not recommended, since according to Benesi and Oliveira (2000), when $5 \%$ of the plants present this disorder, which is characterized by the absence of latex exudation, the operating system should be analyzed and revised. The $3.3 \%$ ethrel dose also caused a high percentage of tapping panel dryness in the RRIM 600 clone. Only the $2.5 \%$ dose did not result in dried plants.

The clones evaluated were in the fifth year of exploitation. When the stimulant is used in older rubber plantations, better yields are obtained, as the bleeding results in the transport of the material that has the function of constructing new tissues for the rubber that will be harvested (Oliveira et al., 2005).

It is believed that the productive increments were not only greater with the increase of the doses due to the percentage of panel drying in these plants. Drying renders them unproductive for an indeterminate period (Silva et al., 2007), thus reducing the average production of the rubber tree. The lowest productive increase in clone PB217 is associated with the higher percentage of tapping panel dryness (Table 1). This clone, when the tapping panel was subjected to the $5 \%$ dose, revealed tapping panel dryness in $33 \%$ of the plants. Thus, the results reported that the higher doses were not compensatory when compared to the $2.5 \%$ dose, due to the low increase of production and the large percentage of plants with tapping panel dryness.

During the development of the research, the plants that were submitted to higher doses showed the beginning of drying, and with the work to the end, these plants showed drying in every panel, leaving them unproductive for an indeterminate time. Larger doses are believed to be directly related to tapping panel dryness due to the prolongation of the exudation period. The higher incidence of tapping panel dryness is associated with increased concentration and frequency of application of the ethrel stimulant (Gébelin et al., 2013).

Tapping panel dryness is a physiological condition, caused by bleeding intensity and can also be caused by stimulation (Gonçalves et al., 2006). Thus, even if the 5\% dose resulted in higher yields, its use is not indicated because it causes a high percentage of tapping panel dryness, as the $3.3 \%$ dose is not recommended, even if the holder of the patent of the stimulator product recommend it, in function of also provoking tapping panel dryness in a large number of plants.

The higher tapping panel dryness at higher doses can be explained, according to Boatman (1966), by the higher ethylene release by ethephon, which interferes in the mechanism of blocking the latex flow with increased exudation period, resulting in higher productivity. Ethylene acts on the membranes of the lutoids and accelerates the action of the invertase on the depletion of the sucrose molecule (Shi et al., 2016). Immediately after the application of stimulant, there is an increase in the sucrose concentration in the laticiferous, but with the course of the process there is a reduction of these levels. A high sucrose content is essential for maintaining the production response.

According to Conduru (1986), the use of a stimulating substance that allows the increase of latex flow through bleeding, has compensated for the lower number of cuts in the low frequency system, allowing to reach the two basic factors of production, physiological and economic. Among the exploration systems, those that use low cut-off frequencies, associated with the

Revista Árvore. 2017;41(5):e410511

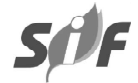


use of stimulant, which, in addition to reducing labor costs, deserve special mention (Oliveira et al., 2005).

The use of the stimulant in tapping panel is essential to ensure better productivities. The percentage of increase in production in the clones submitted to the $2.5 \%$ dose in relation to the control was $52 \%$ in the clone PR 255, 26\% in the clone PB 217 and 51\% in the clone RRIM 600. The productive responses, as can be observed, depend on each clone, the bleeding system to be adopted, the genetics of the clone and its adaptation and the area to be implanted. These factors must be evaluated for the implementation of a production management (Bernardes et al., 1990).

\section{CONCLUSION}

Rubber production is positively affected with increasing ethrel doses, but this increase causes a higher incidence of tapping panel dryness. Thus, it is recommended to use the ethrel $2.5 \%$ dose for the production guarantee without causing the tapping panel dryness. The clone less affected by tapping panel dryness and consequently more productive was PR255.

\section{REFERENCES}

Benesi JFC, Oliveira MA. Sangrador de seringueira: sangria de seringueira. São Paulo: SENAR; 2000.57 p.

Bernardes NS, Castro PRC, Martins AM. Fatores ligado a escolha do sistema de exploração. In: Bernardes MS, editor. Sangria da seringueira. Piracicaba: Esalq; 1990. p. 45-88.

Boatman SG. Estudo fisiológico preliminares sobre a promoção do fluxo de látex por reguladores de crescimento de plantio. Jornal da Malásia. 1966;19(5):243-58.

Borracha Natural Brasileira. Borracha natural. 2011 [cited 2016 Nov 27]. Available from: http:// www.borrachanatural.agr.br/borrachanatural.php

Climate-Data.org. 2016 [cited 2016 Nov 27]. Available from: http://pt.climate-data.org/location/ 312690/

Conduru JMH No. Sistema e exploração com frequência reduzida de sangria e uso de estimulante. In: Anais do Encontro Nacional sobre
Exploração e Organização de Seringais de Cultivo; 1986; Brasília. Brasília: seed hevea; 1986. p. 45-58.

Corredato RA, Malavasi UC, Malavasi MM. Efeito da frequência da sangria em diferentes clones na produtividade de seringueira. Sci Agrár Parana. 2014;13(4):318-22.

Ethrel PA®. Bula de remédio. Rio de Janeiro: Bayer S. A.; 2005.

Gasparoto L, Pereira JCR. Doenças da seringueira no Brasil. Brasília: Embrapa, Serviço de Produção de Informação; 1997. 168 p.

Gébelin V, Leclercq J, Kuswanhadi, Argout X, Chaidamsari T, Hu S, et al. The small RNA profile in latex from Hevea brasiliensis trees is affected by tapping panel dryness. Tree Physiol. 2013;33(10):1084-98. http://dx.doi.org/10.1093/ treephys/tpt076. PMid:24218245.

Gonçalves PDS, Souza SRD, Brioschi AP, Virgens ADC Fo, May A, Alarcon RSC. Efeito da frequência de sangria e estimulação no desempenho produtivo e econômico de clones de seringueira. Pesqui Agropecu Bras.

2000;35(6):1081-91. http://dx.doi.org/10.1590/S0100204X2000000600003.

Gonçalves PS, Aguiar ATE, Gouvêa LRL. Expressão fenotípica de clones de seringueira na região noroeste do estado de São Paulo. Bragantia. 2006;65(3):389-98. http://dx.doi.org/ 10.1590/S0006-87052006000300004.

Moraes VHF, Moraes LAC. Instruções para aplicação de ethrel em seringal nativo do Amazonas. Manaus: Embrapa Amazônia Ocidental; 2001. p. 1-5. (Instruções Técnicas da Embrapa; no. 13).

Oliveira DM, Oliveira LFM, Viana AAM, Mesquita AC. In: Anais do XIV Congresso dos Pósgranduando da UFLA; 2005; Lavras. Lavras; 2005. p. 1-7.

Pereira AV, Pereira EBC, Benesi JFC. Desempenho de clone de seringueira sob diferentes sistemas de sangria. Bol. Pesqui. Desenvolv.. 2001;16:19.

Rojas JM, Rojas M, Rueda GH, Suárez YJ, Furtado EL. Efecto de sistemas de sangría sobre la 
productividad de Hevea brasiliensis en el Magdalena Medio Santandereano. Rev Colomb Cienc Hortic. 2017;11(1):184-92. http://dx.doi.org/ 10.17584/rcch.2017v11i1.6160.

Shi MJ, Cai FG, Tian WM. Ethrel-stimulated prolongation of latex flow in the rubber tree (Hevea brasiliensis Muell. Arg.): an Hev b 7-like protein acts as a universal antagonist of rubber particle aggregating factors from lutoids and Cserum. J Biochem. 2016;159(2):209-16. http:// dx.doi.org/10.1093/jb/mvv095. PMid:26381537.

Silva JQ, Souza MIT, Gonçalves PS, Aguiar ATE, Gouvêa LRL, Pinotti RN. Viabilidade econômica de diferentes sistemas de sangria em clones de seringueira. Pesqui Agropecu Bras. 2007;42(3):34956. http://dx.doi.org/10.1590/S0100204X2007000300007.

Silva JQ. Sistemas de exploração em clones de seringueira: caracteres agronômicos e viabilidade econômica [dissertação]. Campinas: Instituto Agronômico de Campinas; 2008.

Souza CV, Lorenzi H. Botânica sistemática: guia ilustrado para identificação das famílias de Fanerógamas nativas e exóticas no Brasil, baseado em APG III. 2. ed. Nova Odessa: Instituto Plantarum; 2012. 768 p.

Tupy J, Primot L. Sucrose synthetase in the latex of. Hevea brasiliensis muell. Arg. J Exp Bot. 1982;33(5):988-95. http://dx.doi.org/10.1093/jxb/ 33.5.988.

Venkatachalam P, Thulaseedharan A, Raghothama K. Identification of expression profies of tapping panel dryness (TPD) associated genes from the latex of rubber tree (Hevea brasiliensis Muell. Arg.). Planta. 2007;226(2):499-515. http:// dx.doi.org/10.1007/s00425-007-0500-8. PMid:17356851. 